\title{
EVALUATION OF THE ACCURACY OF ANTIDIDIABETIC AGENTS IN PATIENTS WITH DIABETES MELLITUS TYPE II IN THE INPATIENT INSTALLATION OF ONE OF THE PRIVATE AREA HOSPITALS EAST BEKASI 2020
}

\author{
Febriana Lulu Safitri ${ }^{1^{*}}$, Wahyu Nuraini Hasmar ${ }^{2}$ \\ 1. Department/ Pharmacy Bachelor's Degree, STIKes Mitra Keluarga, Bekasi -Indonesia \\ 2. Department/ Pharmacy Bachelor's Degree, STIKes Mitra Keluarga, Bekasi-Indonesia \\ *Correspondence: Febriana Lulu Safitri | STIKes Mitra Keluaga| febrianalulusafitri@gmail.com
}

\begin{abstract}
Introduction: The selection of appropriate drugs in patients with diabetes mellitus can control the blood sugar levels of a patient. When blood sugar levels can be controlled, then the incidence of complications can be avoided and the numbers of mortality and morbidity in diabetes mellitus will be decreased. The goal of this study is to determine the profile of the use of oral antidiabetic, insulin, or a combination, as well as to assess rationality the use of antidiabetic agents in patients with diabetes mellitus type 2 (DMT2) in the inpatient installation of one of the private hospitals in Bekasi 2020.

Method: The research design used was an observational, descriptive, retrospective approach. Data derived from the medical records of DMT2 patients treated as inpatients at a private hospital in Bekasi Timur 2020.

Results: Results for profile use of the drug antidiabetic agents most widely used in sequence, i.e., drug combinations of insulin with insulin, oral with oral, and insulin with oral. The evaluation of the accuracy of the use of the drug is set based on four parameters, namely the proper indication of $100 \%$, the right drug of $58,33 \%$, the right of the patient to $100 \%$, and the right dose of $97,62 \%$.

Conclusion: It can be concluded that the evaluation of the use of the drug in patients with DMT2 still needs to be done so that the numbers of mortality and morbidity in patients with diabetes mellitus decrease.
\end{abstract}

Keywords: Antidiabetic, Diabetes Mellitus Type 2 (DMT2), Rationality.

Received November 25, 2021; Accepted December 30, 2021

\section{INTRODUCTION}

Diabetes mellitus (DM) is a group of metabolic disorders characterized by hyperglycemia and abnormalities in the metabolism of carbohydrates, fats, and proteins (Ganet, 2015). The International Diabetes Federation (IDF) stated that prevelensi DM in the world by $1.9 \%$ and makes the DM disease the cause of death sequence of 7 in the world. Whereas in 2012 the incidence of DM in the world reached 371 million people, the proportion of DMT2 (DMT2) is as much as 95\% of the human population in the world that suffers from the disease of DM. The high incidence of the disease DMT2 is due to some risk factors that cannot be changed, such as gender, age, and risk factors that can be changed are the habit of smoking, educational level, occupation, physical activity, alcohol consumption, BMI (Body Mass Index), and waist circumference (Teixeira et al., 2011).

The prevalence of DM in the area of West Java, especially in the city of Bekasi, is one of the five largest cities in West Java, and the figures show the prevalence of $1.71 \%$ of the population of residents in the area of West Java. Riskesdas (2018) said that in the area of West Java, the gender most suffering from DM is women (KEMENKES RI, 2019).

Given that the DM disease is one of the metabolic disorders that in an emergency situation can cause some of the complications that lead to a high death rate that is equal to 8.4 million in 2000 and 21.3 million by the year 2030, it is necessary to do research evaluation of the accuracy of the therapy in patients with Type II Diabetes mellitus (DMT2). (Arifin et al., 2006).

Based on the background above, given the high number of events that are occurring in West Java, especially in the area of Bekasi, and the importance of proper handling of therapy for the patient DMT2, it is necessary to study the evaluation of the accuracy of the therapy in DMT2. The accuracy of therapy is influenced by the process of diagnosis, the selection of therapy, therapy, and evaluation of therapy. 
Evaluation of the use of a drug is a process of quality assurance that is structured and should be carried out continuously to ensure that the drugs are given appropriately, safely, and efficiently as well (Arifin et al., 2007).

\section{METHOD}

This research is an observational research design with a descriptive analysis approach or retrospective data retrieval. The place to do this research is one of the private hospitals in East Bekasi. The population of this study were all patients diagnosed with DMT2 who underwent inpatient care in one of the private hospitals in East Bekasi while the sample was taken from the patients who met the inclusion criteria.

Inclusion criteria: Patients fulfill the inclusion criteria as the study sample if they meet the criteria as follows: Patients with DMT2 (NIDDM, Non-Insulin Dependent Diabetes Mellitus) with or without complications, aged 20-79 years, who got the therapy of oral antidiabetics, insulin, or a combination thereof.

Exclution criteria Patients who meet the inclusion criteria cannot be included as samples when the patient data is not complete (i.e., there is no therapeutic anti-diabetic).

The sampling technique used is non-probability sampling with the type of consecutive sampling, meaning that the sample taken is the entire subject of the observation and has fulfilled the inclusion criteria (sample selection) then put into the sample.

Variables in this research include life and the rationality of the use of anti-diabetic drugs. These include age, antidiabetic, appropriate indications, the right drug, the right patient, and the right dose.

\section{RESULTS}

\section{Personalities of the Patients}

\section{According to Gender}

From the table below, it can be seen that patients with DMT2 suffered from many female. The amount of data obtained is 28 , with a percentage of $58 \%$, while for the male gender, the data obtained is as many as 20 , with a percentage of $43 \%$.

Table 1. The characteristics of the Patient DMT2 Based on Gender in RS Private Area East Bekasi 2020

\begin{tabular}{cccc}
\hline No & Gender & Number & \% \\
\hline $\mathbf{1}$ & Male & 20 & $43 \%$ \\
$\mathbf{2}$ & Female & 28 & $58 \%$ \\
\hline & Total & $\mathbf{4 8}$ & $\mathbf{1 0 0 \%}$ \\
\hline
\end{tabular}

\section{Age-Related}

Age data was used in this study to find out the number of DM patients suffering in adults and geriarti. Age is one risk factor for DM. The results obtained in this research showed that the age of patients with DMT2 most suffered from the age range of $41-50$ years, as many as 18 patients (38\%), followed by the age range of 51-60 years, as many as 14 patients (30\%), and most of that is in the age range of 20-30 years, and the lifespan of 81-90 years, as many as 1 patient (2\%).

Table 2. The characteristics of the Patient DMT2 Based on the Age at RS Private Area East Bekasi 2020

\begin{tabular}{cccc} 
No & Age & Number & \% \\
\hline $\mathbf{1}$ & $20-30$ & 1 & $2 \%$ \\
$\mathbf{2}$ & $31-40$ & 7 & $15 \%$ \\
$\mathbf{3}$ & $41-50$ & 18 & $38 \%$ \\
$\mathbf{4}$ & $51-60$ & 14 & $29 \%$ \\
$\mathbf{5}$ & $61-70$ & 5 & $10 \%$ \\
$\mathbf{6}$ & $71-80$ & 2 & $4 \%$ \\
$\mathbf{7}$ & $81-90$ & 1 & $2 \%$ \\
\hline
\end{tabular}




\section{Total}

48

100

\section{Comorbidities}

The table below shows the 6 common diseases in the hospital of the private sector in the Area of Bekasi 2020. In this study, it can be seen that the concomitant diseases, most of which are on the installation of hospitalization in a private hospital in Bekasi, Timur 2020, namely hypertension and fever, are unspecified as much as 5 patients, hypoglicemia as much as 3 patients, and CHF FC II, dyspepsia, and atherosclerotic heart disease by as much as 2 patients.

Table 3. The characteristics of the Patient DMT2 Based on Comorbidities in Private hospitals Area East Bekasi 2020

\begin{tabular}{ccc}
\hline No & Comorbidities & Number (People) \\
\hline $\mathbf{1}$ & Hypertension & 5 \\
$\mathbf{2}$ & Fever, unspecified & 5 \\
$\mathbf{3}$ & Hypoglicemia & 3 \\
$\mathbf{4}$ & CHF FC II & 2 \\
$\mathbf{5}$ & Dyspepsia & 2 \\
$\mathbf{6}$ & Atherosclerotic heart disease & 2 \\
\hline
\end{tabular}

\section{Patterns of Use of Drugs}

From the table below can be known that the pattern of administration used in the RS private area Bekasi Timur is for single and combination. To use a single class of drugs used is a sulfonylurea as much as 3 patients, inhibitors of DPP-4 by 2 patients, and for insulin depen single as much as 1 patient. For the pattern of giving in the combination there are 3 ie combinations of insulin with insulin as much as 5 patients, ODO with ODO as many as 16 patients, and a combination of the latter is insulin with ODO as much as 21 patients.

Table 4. The pattern of Drug Use DM in RS Private Area East Bekasi 2020

\begin{tabular}{ccccc}
\hline No & The Pattern Of & Class/ Type Of Medicine Class/ Type Of Medicine & Number & $\mathbf{\%}$ \\
\hline \multirow{2}{*}{$\mathbf{1}$} & \multirow{3}{*}{ Single } & Sulfonylurea & 3 & 7 \\
& & Inhibitions of DPP-4 & 2 & 4 \\
& & Insulin & 1 & 2 \\
\multirow{3}{*}{$\mathbf{2}$} & \multirow{3}{*}{ Combination } & Combination Insulin & 5 & 10 \\
& & Combination Oral & 16 & 33 \\
& & Combination Insulin + & 21 & 44 \\
& & Oral & $\mathbf{4 8}$ & $\mathbf{1 0 0}$ \\
\hline
\end{tabular}

\section{Drug Abuse Assessment}

The evaluation of the accuracy of the therapy antidiabetic in this study is based on the Guidelines of the Consensus Control and Prevention of Type 2 Diabetes Mellitus in Indonesia (2011), AHFS (2011), and ADA (2021). The evaluation criteria include appropriate indications, the right drug, the right patient, and the right dose.

Table 5. Drug Use evaluation of DM in RS Private Area East Bekasi 2020

\begin{tabular}{cccc}
\hline No & Kriteria & Tepat $(\%)$ & Tidak Tepat (\%) \\
\hline $\mathbf{1}$ & Tepat Indikasi & 100 & - \\
$\mathbf{2}$ & Tepat Obat & 58,33 & 41,67 \\
$\mathbf{3}$ & Tepat Pasien & 100 & - \\
$\mathbf{4}$ & Tepat Dosis & 97,62 & 2,38 \\
\hline
\end{tabular}




\section{DISCUSSION}

Based on the research conducted, can be detected in patients with diabetes mellitus (DM) in one of the private hospitals in East Bekasi during the year 2020, as many as 54 patients. There are 48 patients who met the inclusion criteria and 6 patients who entered the exclusion criteria because they do not get treatment for diabetes.

\section{Personalities of the Patients}

\section{According to Gender}

Based on the results obtained regarding the distribution of patients by gender above, it can be seen that women are more at high risk than men, with 57\% more diagnosed with DM disease compared with $43 \%$. On Riskesdas (2018), the prevalence of DM disease in women is higher than in men, with a ratio of $1.78 \%$ to $1.21 \%$ (and on) (KEMENKES RI, 2020).

The results of this study are in line with research conducted by Hongdiyanto et al. (2013) showing that the prevalence of DM in women is higher compared to men because physically, women have an increased opportunity to the index of the larger body, the syndrome of the monthly cycle (premenstrual syndrome), and post-menopause that causes the distribution of body fat to easily accumulate (Hongdiyanto et al., 2014). Men are also susceptible to DMT2, although their body mass index (BMI) is smaller than women. In addition, if the hormone testosterone in males is still within normal levels, then the accumulation of fat in the abdominal area will also be low. However, if at excess levels, then the accumulation of fat in the abdominal area will be increased so as to cause the occurrence of obesity. It is the reason that men are at risk of being exposed to DMT2 (Logue et al., 2014).

\section{By Age}

In the table of the distribution of patients by age above can be seen that patients with DMT2 is more common in the age of 41-50 years as many as $36 \%$. Generally patients with DMT2 occurs at the age above 40 years so need to do a screening of the first covers blood sugar test fasting, blood sugar 2 hours after eating (GD2PP) and HbA1C test (Dennedy et al., 2015). The results obtained are in line with the results of the research of Nurul (2016) that the age of patients with DMT2 the most high that is in the age range 4165 years as many as 56 cases $(77,8 \%)$. Increased risk of DM along with increasing age, especially at the age of $>40$ years, the cause ie in the age of the increased glucose intolerance. The process of aging causes the $\beta$ cells of the pancreas decreased in the insulin-producing (Trisnawati, 2013).

\section{Comorbidities}

Concomitant diseases most is obtained hypertension, hypertension is known to accelerate and aggravate complications-complications due to diabetes such as coronary heart disease, stroke, nephropathy, retinopathy, retinopatik diabetic, and cardiovascular disease due to diabetes, which can be doubled if accompanied by hypertension. Insulin resistance plays an important role in the pathogenesis of hypertension. Insulin can stimulate the sympathetic nerves, increase the reabsorption of sodium in kidney, affecting the transport of the cation and the resulting hypertrophy of the smooth muscle cells of blood vessels which will result in a rise in blood pressure (Sinaga, 2016). DMT2 is a risk factor against the occurrence of hypertension is not controlled, because the DMT2 can affect the increase in the reninangiotensin-aldosterone system, retention of salt and fluids, as well as the rigidity of the vascular so as to affect high blood pressure (Ichsantiarini, 2013).

\section{Patterns of Use of Drugs}

In the table below, the results obtained from the use of the drug antidiabetic prescribed by a doctor show that combination therapy is more widely used compared with antidiabetic single. Antidiabetic single injections used are insulin glargine (Ezelin) and insulin aspart (Novorapid F.pen). Insulin is used for patients with DMT2 who have a drop in glucose levels because the levels owned by the patient are already very high. Patients with DMT2 whose blood glucose levels are not controlled with oral anti-diabetics require insulin as a single therapy or in combination with oral medications. Insulin is given earlier and better, especially with regard to glokugenesis. This can be seen by the improvement in the function of pancreatic beta cells and the insulin effect, which can be advantageous in relation to the complications of DM (Haines et al., 2019). 
For oral drugs, single used in one of the private hospitals in Bekasi Timur 2020 is the class of sulfonylureas (glimepirid, gliquidon, gluronorm) and other groups that are used, namely the class of inhibitors of DPP-4 (sitagliptin, linagliptin). The class of sulfonylureas is the drug of first choice (drug of choice) for patients with DM who are new adults with normal body weight and less, as well as those who have never experienced ketoacidosis before. These drugs work by stimulating the secretion of insulin in the pancreas gland, so it is only effective if the beta cells of the pancreas can still reproduce. Because sulfonylurea compounds absorb well through the intestines, they can be administered orally (Kovy, 2019). Oral medication is used in addition to the class of sulfonylureas, namely the class of inhibitors of DPP-4. These drugs have been approved for use in patients who failed to achieve adequate glycemic control with the use of metformin, sulfonylureas, or tiazolidondion (Haines et al., 2019).

In addition to oral medication that is given for a single private Hospital daerah Bekasi Timur also used insulin. Insulin therapy can be given in a single form of insulin work: fast (rapid acting insulin), medium (intermediate acting), long (long acting), or insulin mixture remains (premixed insulin) (PERKENI, 2015). The insulin used is insulin aspart (Novorapid F. Pen®) and insulin glargine (Ezelin®). Insulin aspart and insulin glargine are included in the insulin working length (long acting).

In the private hospital Bekasi Timur areas, in addition to using a single treatment for patients with DMT2, they also use the drug combination. The combinations used are also an assortment of combinations of oral with oral, oral with insulin, and insulin with insulin. Use the combination of insulin with insulin. The most widely used is the Novorapid F. Pen ${ }^{\circledR}+$ Levemir F. Pen®. The combination of Novorapid F. Pen ${ }^{\circledR}$ and Levemir F. Pen ${ }^{\circledR}$ is given to patients with blood sugar levels $200 \mathrm{mg} / \mathrm{dL}$. Despite the use of oral antidiabetic drugs, the use of insulin from the beginning can provide better clinical results, especially with regard to the glukotoksisitas (Nurul Dini Sepmawati, 2016). Novorapid F. Pen ${ }^{\circledR}$ is insulin that works faster and Levemir F. Pen ${ }^{\circledR}$ is insulin that works long when compared with the use of this type of insulin, which produces a rapid onset and duration of work so that it can mimic the profile of normal insulin in the human body (Nurul Dini Sepmawati, 2016).

The most widely used combination of oral antidiabetic drugs is the combination of metformin with glimepiride. The combination of the drugs metformin and glimepiride significantly lowers levels of fasting blood sugar, blood sugar postprandial, the levels of HbAlc, and the levels of Hcy (homocysteine). Besides, it is also able to reduce levels of total cholesterol and triglycerides, lower LDL and raise HDL, so it can reduce the risk of cardiovascular patients (Nova et al., 2017). The working mechanism of glimepiride is to stimulate the secretion of insulin and metformin to reduce hepatic gluconeogenesis, increase insulin sensitivity, and reduce the absorption of glucose in the gastrointestinal tract. So, based on the mechanism of action of the combination of drugs, glimepiride with metformin can decrease blood glucose more quickly than the single treatment of each drug (Haines et al., 2019).

The Novorapid F. Pen ${ }^{\circledR}+$ Pionix M® combination of insulin and oral glucose is the most commonly used (see appendix).Pionix $M \circledR$ is a drug that combines pioglitazone and metformin.Pioglitazone is an antidiabetic drug group tiazolidindion. The mechanism of this class is to reduce insulin resistance, regulate the production of adipocytes and free fatty acids as well as glucose metabolism, resulting in increased insulin sensitivity in adipose tissue, liver, and skeletal muscle (Haines et al., 2019). While metformin has a working mechanism, namely by increasing the sesitivitas of insulin in the liver tissue and peripheral (muscle) areas, it allows an increase in glucose uptake. Metformin can reduce the level of HbA1c by $1.5 \%$ to $2 \%$ (Ganet, 2010). Combination therapy between insulin and oral antidiabetic drugs can generally achieve control of blood glucose with insulin doses that are quite small (Perkeni, 2015).

\section{Drug Abuse Assessment \\ Proper Indications}

Proper indication of the accuracy of the use of antidiabetic agents on the basis of the diagnosis established by the doctor. Every drug has a spectrum of therapy-specific, so the administration should be in accordance with the disease. Based on table 5 it can be seen that of the 48 patients with DM who underwent inpatient treatment in one of the private hospitals Bekasi year 2020 according to the guidelines used by the Endocrinology Society of Indonesia (2015) based on the criteria of exact indication that otherwise meet the criteria of $100 \%$ due to administration of the drug antidiabetic in accordance with the diagnosis that has been set by a doctor that DMT2/NIDDM. 
In a study conducted by Amelia (2019), namely the rationality of the use of antidiabetic drugs in patients with DMT2 in RSUD, Prof. Dr. W. Z. Johanes, Kupang period 2018, everything was a precise indication or $100 \%$ right indication. However, in the research conducted by Arnold (2014) for the evaluation of the reasonableness treatment of type 2 diabetes mellitus in hospitalized patients in RSUP. Dr. R. D. Kandou Manado tahun 2013 results obtained on the evaluation of precise indication ie of 46 patients as much as $86,96 \%$ exact indication. This difference is due to the research conducted by Arnold how to determine a precise indication based on the value of the GDS of the patient while in this study viewed from the doctor's diagnosis.

\section{Right Drug}

The right medicine is when therapeutic efforts are taken in accordance with the diagnosis so that the selected drugs can pose a therapeutic effect in accordance with the disease (Menkes, 2011). Based on table 5.3 above, it can be seen that of the 48 patients with diabetes mellitus undergoing treatment at the inpatient installation of one of the private hospitals in the area, Bekasi Timur 2020, according to the guidelines used by the American Diabetes Association (ADA) 2018 and standards PERKENI 2011 based on the criteria of appropriate drugs who otherwise meet the criteria of 58,33\% and improper drugs, 41,67\%. Evaluation of the accuracy of the drug, which was done in this study by comparing the value of HbA1c of patients with algorithm-based treatment guidelines that are used. Of the 48 patients in the private hospital in the area of Bekasi Timur, a total of 23 patients had data on HbA1c and 25 patients did not have it. For patients who do not have HbA1c values, then in conversion with the table listed in the appendix.

In a study conducted by Corry (2016) to get the results related to the right of the drug, it was found that in 32 patients as much as $15.62 \%$ of the right drug, which means the presentation not to the right of the drug in patients with DMT2 in RSU Yarsi Pontianak is still high. The same thing happens in the research by Nurul (2016), which states that out of 72 patients, as much as $95.8 \%$ of the right drug, which means there is still no treatment in patients with DMT2 improper drug.

\section{Appropriate Patient}

The right patient, namely the administration of drugs that will be used, must consider the condition of the patient. Based on table 5.3 above, it can be seen that of the 48 patients with diabetes mellitus undergoing treatment at the inpatient installation of one of the private hospitals in the area Bekasi Timur 2020, according to the guidelines used by the AHFS (2011) \& Dipiro (2015), based on the criteria of appropriate patients, meet the criteria for $100 \%$. In the guide book, which is used to set right patients with the see- counter indication of each drug, with concomitant diseases of the patient. Research conducted by Nurul (2016) to get the results related to the right of the patient, that is, of the 72 patients, as much as 95,85\% right of the patient. The results obtained by Nurul show that there is still a need for drugs for diabetes patients. It happens also in a study conducted by Cory (2016), which states that of the 32 patients, as much as $87.5 \%$ are appropriate patients.

\section{The Correct Dose}

The right dose is when the use of the drug should be in accordance with the therapeutic range of the drug. Based on table 5 above, it can be seen that of the 48 patients with diabetes mellitus undergoing treatment at the inpatient installation of one of the private hospitals in the area of Bekasi year 2020, according to the guidelines used by the Endocrinology Society of Indonesia (2015). Due to the limitations of the data, the insulin dose was not evaluated in this study, which prevented the evaluation of the dose for the oral antidiabetic drugs. From the results of the analysis of the entire use of oral antidiabetic drugs, the results obtained showed $97,62 \%$ exact dosage and $2.38 \%$ not appropriate dose due to patients with medical record number $25 \times x \times x$ the use of the drug trajenta duo used not in accordance with the standards of PERKENI 2011. On a guide, the maximum dose a day for a drug called trajenta is $5 \mathrm{mg} / 1 \mathrm{~g}$. However, the use in patients is $7.5 \mathrm{mg} / 1.5 \mathrm{~g}$, so it does not fit.

In the research conducted by Arnold (2014) to get the results related to the exact dosage, that is, from 46 patients, $97,32 \%$ of the exact dosage. It shows almost the same results in RSUP. Dr. D. Kandou Manado 2013 with a private hospital in the Bekasi Timur 2020 area. 


\section{CONCLUSION}

Based on the results of research that has been conducted in one of the private hospitals Bekasi Timur 2020, it can be concluded as follows:

1. Based on the results of the research profile of the use of antidiabetics in one of the private hospitals in Bekasi, Timur 2020, the most widely used treatment is the use of drugs in combination. The use of the most widely used drug is insulin with insulin, then the combination of oral antidiabetic with oral antidiabetic, and the combination of insulin with oral.

2. The results of the evaluation of therapy in patients with DMT2 in the private hospital Daerah Bekasi Timur 2020, of the 48 patients, is a proper indication of $100 \%$, the right drug $58,33 \%$, the right of the patient to $100 \%$, and the right dose $97,62 \%$.

3. Based on the research that has been done, it should be done with advanced research with the approach of prospective. It aims to improve the quality of health of patients and to determine whether a given drug can cause a significant decrease in glucose.

\section{REFERENCE}

Arifin, I., Prasetyaningrum, E., \& Andayani, T. M. (2006). Evaluasi Kerasionalan Pengobatan Diabetes Mellitus Tipe 2 Pada Pasien Rawat Inap di Rumah Sakit Bhakti Tamtama Semarang Tahun 2006. Jurnal Ilmu Farmasi Dan Farmasi Klinik, 4, $23-29$.

Dennedy, M. C., Rizza, R. A., \& Dinneen, S. F. (2015). Classification and Diagnosis of Diabetes Mellitus. Endocrinology: Adult and Pediatric, 1-2(January), 662-671.e2. https://doi.org/10.1016/B978-0-32318907-1.00038-X

Ganet-Schoeller, M., \& Ducamp, M. (2010). LPV control for flexible launcher. In AIAA Guidance, Navigation, and Control Conference. https://doi.org/10.2514/6.2010-8193

Haines et al, 2019, daniel, A. goleman, Richard, boyatzis, Mckee, Haines et al, 2019, daniel, A. goleman, Richard, boyatzis, Mckee, Haines et al, 2019, daniel, A. goleman, Richard, boyatzis, \& Mckee. (2019). Rasionalitas Penggunaan Obat Antidiabetes Pada Pasien Dm Tipe 2 Rawat Inap Di Rsud Prof. Dr. W. Z. Johannes Kupang Periode 2018. Journal of Chemical Information and Modeling, 53(9), 1689-1699.

Hongdiyanto, A., Yamlean, P. V. Y., \& Supriati, S. (2014). Evaluasi Kerasionalan Pengobatan Diabetes Melitus Tipe 2 Pada Pasien Rawat Inap Di Rsup Prof. Dr. R. D. Kandou Manado Tahun 2013. Pharmacon, 3(2), 77-87. https://doi.org/10.35799/pha.3.2014.4775

Ichsantiarini, A. P., \& Nugroho, P. (2013). Hubungan Diabetes Melitus Tipe 2 Dengan Kendali Tekanan Darah Pada Pasien Hipertensi Rumah Sakit Dr. Cipto Mangunkusumo. 1-15.

KEMENKES RI. (2019). Hari Diabetes Sedunia Tahun 2018. Pusat Data Dan Informasi Kementrian Kesehatan RI, 1-8.

Kementrian Kesehatan RI. (2020). 2020-Diabetes-Melitus.pdf. In Pusat Data dan Informasi Kementrian Kesehatan RI (pp. 1-10).

Kovy, M. (2019). Evaluasi Penggunaan Obat Antidiabetes Oral pada Pasien Diabetes Melitus Tipe II Rawat Jalan di RSUD Prof. Dr. Soekandar Tahun 2016. Journal of Chemical Information and Modeling, 53(9), 1689-1699.

Logue, J., Walker, J. J., Colhoun, H., Leese, G. P., \& Lindsay, R. S. (2014). Europe PMC Funders Group Do men develop type 2 diabetes at lower body mass indices than women? 54(12), 3003-3006. https://doi.org/10.1007/s00125-011-2313-3.Do

Menkes, R. (2011). Modul penggunaan obat rasional. Kementerian Kesehatan RI, 1-192.

Nurul Dini Sepmawati. (2016). Evaluasi Ketepatan Terapi Pada Pasien Diabetes Mellitus Tipe 2 Di Instalasi Rawat Inap Rs “A” Periode Januari - Juni 2015. Farmasi, 1, 1-12.

Nova, E., Antidiabetic, O., Interactions, D., Type, I. N., \& Patients, D. (2017). Evaluasi Dosis Dan Interaksi Obat Antidiabetika Oral Pada Pasien Diabetes Mellitus Tipe Ii Evaluation Of Oral Antidiabetic Dosing And Drug Interactions In Type Ii Diabetic Patients. 7(Dm), 191-196.

PERKENI. (2015). Panduan Pelaksanaan DM Tipe 2 pada Individu Dewasa di Bulan Ramadan. Panduan Penatalaksanaan DM Tipe 2 Pada Individu Dewasa Di Bulan Ramadan, 35.

Sinaga. (2016). Evaluasi Kerasionalan Pengobatan Pada Pasien Diabetes Melitus Tipe II di Instalasi Rawat Inap RSU Yarsi Pontianak

Teixeira-lemos, E., Nunes, S., Teixeira, F., \& Reis, F. (2011). Regular physical exercise training assists in 


\section{Jurnal Mitra Kesehatan (JMK)}

DOI: $10.47522 /$ jmk.v1iIAHSC.116

preventing type 2 diabetes development: focus on its antioxidant and anti-inflammatory properties. 115.

Trisnawati, S. K., \& Setyorogo, S. (2013). Faktor Risiko Kejadian Diabetes Melitus Tipe II Di Puskesmas Kecamatan Cengkareng Jakarta Barat Tahun 2012. Jurnal Ilmiah Kesehatan, 5(1), 6-11. 